\title{
SAPERE AUDE
}

\section{EDITORIAL}

DOSSIÊ: DEMOCRACIA EM CRISE

Sapere aude - v. 9, n. 17, p. 6-11, Jan./jun. 2018 - ISSN: 2177-6342

\section{QUE DEMOCRACIA?}

Robson Sávio Reis Souza*

Na edição de 2017 do Latinobarômetro, apenas 13\% dos brasileiros consultados se declararam satisfeitos com o funcionamento da democracia. E mais: somente $1 \%$ dos brasileiros acha que o país vive uma "democracia plena", e 97\% avaliam que o governo trabalha apenas para atender os interesses de "grupos poderosos".

A bem da verdade, apesar de a Constituição Federal de 1988 ter ampliado, no plano formal, os direitos em nosso país, qualquer cidadão mais atento poderá constatar que a democracia não chegou, de fato, às periferias das grandes cidades brasileiras: a situação de desigualdade social e a violência seletiva contra pobres e negros nesses locais confirmam que no Brasil todos não são iguais perante a lei, e a democracia é um arranjo para a classe média. Afinal, é possível democracia sem cidadania?

Desde sua origem, na Grécia antiga, a democracia é um sistema de hierarquização do poder arquitetado por atores políticos que têm múltiplos interesses (políticos, religiosos, de classe...) por esse modelo de governança.

Como sabemos, nos seus primórdios, há cerca de 2.500 anos, estavam excluídos dos processos decisórios as mulheres, os jovens, os estrangeiros e os escravos. Ou seja, na democracia, cuja palavra significa "governo do povo", somente os homens livres deliberavam sobre os rumos da polis. O demos se restringia, portanto, a alguns; não a todos.

A história contada desde então não problematiza o fato de que a democracia grega funcionou porque a classe antagônica estava excluída do processo deliberativo: os escravos não poderiam, jamais, participar das decisões dos homens livres. Em outras palavras, a democracia grega se edificou numa ordem social escravagista.

\footnotetext{
* Licenciado em filosofia e doutor em Ciências Sociais; é coordenador do Núcleo de Estudos Sociopolíticos da PUC Minas. E-mail: robsonsavio@gmail.com.
} 
Ora, se os escravos pudessem decidir nas mesmas condições que os homens livres, as leis seriam alteradas e eles, os escravos, acabariam com a servidão. Resumindo: já no seu nascedouro, a democracia grega apontava que interesses em contradição são inconciliáveis e, para o funcionamento desse sistema, alguns sempre terão vantagens.

A ideia segundo a qual a democracia é um governo do povo é, na verdade, um exercício retórico. Os detentores do poder, em cada época histórica, se servem desse subterfúgio, uma narrativa muito bem construída, para convencer os cidadãos de que os governos democráticos são governos populares e que atendem aos interesses de todos.

A partir do século XVI, a experiência democrática grega é retomada com a criação dos chamados estados-nação. E, gradualmente, com a chegada dos burgueses ao centro do poder foi-se consolidando no Ocidente outra ideia segundo a qual democracia e capitalismo são sinônimos.

Assim, nas democracias contemporâneas os homens (brancos), detentores do capital, os chamados burgueses, assumiram o controle do poder. E, como ocorreu na Grécia antiga, para que o sistema democrático funcionasse nesse novo contexto histórico, era preciso que a classe antagônica, portanto, os operários, a maioria da população, fosse controlada ou excluída dos processos decisórios.

Esse controle e/ou exclusão se concretizam utilizando-se de várias estratégias. Nas democracias representativas, por exemplo, os sistemas judiciário e eleitoral são montados para passar a impressão de que há isonomia na competição eleitoral e no acesso ao poder. $\mathrm{Na}$ verdade, há mecanismos (a legislação eleitoral brasileira, por exemplo) que impedem a participação efetiva da maioria da população na disputa isonômica do poder e limita o acesso popular nos processos decisórios.

Com a "doutrinação midiática", os eleitores pensam que estão elegendo seus representantes. $\mathrm{Na}$ verdade, elegem, majoritariamente, os donos do capital ou os seus prepostos e as elites partidárias que colonizam a maioria dos partidos, inclusas as agremiações autodenominadas de "esquerdas". Pouquíssimos representantes do "chão da fábrica" chegam aos postos de poder. E quando isso ocorre, geralmente precisam se adequar às "regras do jogo"

Nas democracias representativas, a ideia de eleições livres, diretas e regulares esconde, sorrateiramente, uma série de regras procedimentais que impedem a representação efetiva da maioria da população. É só verificarmos o perfil socioeconômico dos representantes eleitos nas câmaras de vereadores, assembleias e no Congresso Nacional em nosso país. 
Constataremos, cabalmente, que a maioria esmagadora da população não está representada (de fato) nas casas legislativas, apesar de as regras procedimentais da democracia (eleições livres, diretas e regulares; mídia livre, etc.) funcionarem perfeitamente. O mesmo se dá em relação ao executivo: os donos do dinheiro e as elites partidárias sempre se beneficiam das regras eleitorais e da ação direta do sistema de justiça para dominarem esse poder.

Por óbvio, se a democracia fosse realmente levada às últimas consequências, os trabalhadores, que são a maioria, teriam o mesmo poder dos burgueses. E, sendo maioria, os operários definiriam os rumos da sociedade.

$\mathrm{Na}$ verdade, há poucas democracias e muitas aristocracias (governos constituídos por aqueles considerados como os melhores ou os mais capazes) e plutocracias (governos dos ricos; ou seja, daqueles que usam do poder econômico para acessar o poder estatal).

No caso do Brasil atual, temos uma cleptocracia: um governo de larápios, perpetradores de fraudes, operadores da corrupção em concorrências e licitações públicas e até líderes do tráfico de drogas que ocupam os poderes dessa pseudorrepública e assumiram o controle do governo através de um golpe parlamentar-judiciário-midiático-empresarial-elitista. E às favas o povo...

Outra forma de domínio das democracias pelas elites se dá através da burocracia estatal. No sistema democrático, os representantes eleitos (membros das elites econômicas, políticas, intelectuais, religiosas) controlam a aprovação de leis de interesse dessas minorias; administram a justiça favorecendo sempre essas classes e manipulam a chamada opinião pública através de ideologias arquitetadas pelos seus parceiros nos meios de comunicação empresarial.

Outro exemplo de manipulação falaciosa do conceito de democracia se dá através da ciência. Para substituir deus, origem do poder até a Idade Moderna, o positivismo e as ciências sociais trataram de consolidar a ideia segundo a qual o conhecimento tem a última palavra em relação aos conflitos e dilemas sociais e políticos. A deusa, agora, é a ciência.

Você já reparou que um especialista é sempre chamado a pontificar sobre os problemas sociais, políticos e econômicos, dando a "última palavra"? Você percebe que esse especialista ou cientista é, na maioria das vezes, um cidadão da classe média ou um preposto das classes dominantes? (É só ligar a Globonews ou ler os jornalões brasileiros e você perceberá que o "cientista" sempre dá a receita em nome da sociedade, e essa receita, invariavelmente, é para a manutenção do status quo). 
Não é à toa que a colonização da academia é um dos mais cuidadosos meios para a manutenção do establishment. Você pode até conhecer um cientista que destoa do pensamento hegemônico, mas observe: para que ele participe da "opinião publicada que insiste em se arvorar como opinião pública" é preciso ser um dissidente sempre dócil. Caso contrário, entra para o index da mídia empresarial.

Aliás, a ideia de democracia capitalista se transformou num dogma, a confirmar que devemos ter fé nessa narrativa. E, pobres daqueles que questionam a democracia capitalista.

Chega a ser ridículo ler artigos de renomados cientistas sociais e políticos, economistas, historiadores, filósofos a defenderem como "normal" a democracia procedimental brasileira. Certamente, não vivem o dilema da fome, do desemprego e das condições análogas à escravidão que fazem parte do cotidiano de $70 \%$ dos brasileiros. E acham que é "natural" uma democracia nesses moldes. São os colonizados de uma ciência serviçal do sistema capitalista.

Quer conhecer como boa parte dos cientistas brasileiros (de renome) é colonizada? É só pesquisar sobre as bolsas de financiamento da pós-graduação no exterior, os congressos e eventos científicos internacionais e as parcerias institucionais das nossas universidades e centros de pesquisas financiadas por fundações e think tanks norte-americanos. Você perceberá por que a ciência brasileira, no geral, é voltada para o sucesso individual e o servilismo ao capitalismo, salvo exceções.

Concluímos, até aqui, que a democracia é uma narrativa que atende a certos interesses. Um conceito (teórico) muito bem arquitetado e consolidado que não se concretiza no mundo real; afinal, não há experiência concreta de "governo do povo".

Temos que admitir, não obstante, que os regimes democráticos realizaram importantes avanços sociais no século XX, principalmente após a Segunda Guerra Mundial. Através de pactos entre elites ou na adequação das demandas das esquerdas socialistas aos modelos democráticos capitalistas, tais regimes melhoraram (e muito) a vida dos trabalhadores em diversos países. Noutros (países), as migalhas concedidas aos trabalhadores foram abundantes, passando a impressão de que o povo, ou seja, a maioria dos trabalhadores, decidia o rumo de sua vida.

Ademais, a decadência de outros modelos de governança consolidou a crença na eficácia inquestionável das democracias capitalistas. Experiências de governos socialistas perderam a batalha (da disputa acerca do melhor modelo de governança) na mídia 
empresarial, principal front de manutenção dos governos democrático-capitalistas na atualidade.

No Brasil, nunca tivemos uma democracia real. Historicamente, as elites nacionais sempre se apropriaram do erário e do Estado para se locupletarem e ampliarem seus negócios e domínios, oferecendo sobejos ao povo. Em alguns raríssimos momentos, houve pífia expansão do estado social, não alterando substantivamente uma ordem social excludente, injusta, perversa e violenta.

Não experimentamos, ao longo do século XX, o "século dos direitos" (Bobbio), mudanças estruturais na nossa sociedade. A Constituição Federal de 1988, tardiamente, propiciou alguns parcos avanços sociais à maioria dos brasileiros. Governos mais sensíveis aos trabalhadores, como nas gestões do Partido do Trabalhadores, colocaram o estado um pouquinho mais a serviço dos setores historicamente excluídos e marginalizados.

Mas, veio o golpe de 2016. E os neocoronéis, filhos dos eternos saqueadores do erário e das riquezas nacionais, tomaram de assalto o poder, novamente. E, como uma horda de bárbaros sem temor e pudor, respaldados pela velha justiça da Casa Grande e vitaminados pela mídia empresarial e por parcela da classe média dos privilegiados, lançaram o país de volta ao passado.

Não à toa, os golpistas recorreram ao lema da velha república (criada num golpe por latifundiários, maçons, militares e positivistas), "ordem e progresso", para caracterizar um governo que, entre inúmeros retrocessos históricos, sociais e políticos não tem um pingo de vergonha em praticamente legalizar o trabalho análogo à escravidão, vender a preço de banana nossas riquezas e anistiar os latifundiários, os banqueiros e os grandes empresários eternos larápios do patrimônio e das riquezas nacionais.

O golpe confirmou a tese: a democracia capitalista brasileira só é boa enquanto uns poucos se locupletam dos frutos do trabalho da maioria. E quando essas castas de privilegiados resolvem se unir para defender seus interesses a qualquer custo, nem mesmo as aparências (democráticas) são mantidas.

No momento atual (junho de 2018), o estado brasileiro está duplamente tutelado: pelo sistema judicial-policial (polícias, Ministério Público e Judiciário) e pelas Forças Armadas -, cada vez mais protagonistas da política. O povo está totalmente alijado de qualquer protagonismo político.

No Brasil nunca tivemos um processo revolucionário de cima para baixo. As poucas tentativas de sublevação do andar de baixo foram violentamente sufocadas pelas elites no 
poder. Também nunca convivemos com uma guerra - que, às vezes, desperta solidariedade entre as classes. Talvez, por isso, os trabalhadores, maioria da população, sempre se contentaram com as migalhas. Os poucos avanços sociais só foram possíveis em governos que vigoraram através de pactos entre elites.

Nas condições históricas atuais, não há espaço para processos revolucionários. O nível de controle social e político nunca foi tão sofisticado. $\mathrm{O}$ individualismo, exacerbado pelo capitalismo, destrói a solidariedade e produz seres humanos que se preocupam só com seus umbigos.

Nesse contexto, defender essa democracia à brasileira e nos iludirmos na crença segundo a qual eleições regulares corrigirão as mazelas históricas dessa "coisa pública" que é (e sempre foi) de e para poucos deve ser objeto de reflexão.

Para todos os efeitos, é sempre importante pensarmos sobre democracia. E esta publicação oferece uma colaboração importante nesse sentido. Boa leitura! 